\title{
FORMULASI VANISHING CREAM MINYAK ATSIRI RIMPANG JAHE (Zingiber officinale Roxb) DAN UJI AKTIVITAS REPELAN TERHADAP NYAMUK Aedes aegypti BETINA
}

\section{THE VANISHING CREAM FORMULATION OF GINGER RHIZOME ESSENTIAL OIL AND ITS REPELLANT EFFECT TO FEMALE Aedes Aegypti MOSQUITO}

\author{
Oleh : Azis Ikhsanudin \\ Fakultas Farmasi Universitas Ahmad Dahlan \\ Jln. Prod. Dr. Supomo Yogyakarta, Telp. (0274) 379418
}

\begin{abstract}
Abstrak
Minyak atsiri rimpang jahe merupakan bahan alam yang telah terbukti secara ilmiah) mempunyai efek repelan terhadap nyamuk. Penelitian ini bertujuan untuk mengetahui pengaruh penambahan minyak atsiri rimpang jahe (Zingiber officinale Roxb) terhadap sifat fisik vanishing cream dan efek repelan terhadap nyamuk Aedes aegypti betina. Rimpang jahe diisolasi minyak atsirinya dengan cara destilasi uap air yang kemudian di uji sifat fisiknya meliputi uji viskositas, daya lekat dan daya sebar serta repelan. Kelima formula vanishing cream dengan variasi konsentrasi minyak atsiri rimpang jahe (Zingiber officinale Roxb), dimana formula $I: 6,25 \% \mathrm{v} / \mathrm{b}$; formula II: 12,5\%v/b, The Vanishing Cream Formulation of Ginger Rhizome Essential Oil and Its Repellant Effect to Female Aedes aegypti Mosquitoformula III : 15\% $/ \mathrm{v}$, formula IV: $20 \% \mathrm{v} / \mathrm{b}$ dan formula $\mathrm{V}: 25 \% \mathrm{v} / \mathrm{b}$. Kelima formula tersebut kemudian diuji sifat fisiknya yang meliputi uji viskositas, uji daya lekat dan daya sebar serta selanjutnya diuji efek repelan terhadap nyamuk Aedes aegypti betina sebanyak 20 ekor per kandang dengan probandus tangan relawan berjenis kelamin perempuan sebanyak 4 orang. Hasil kemudian dianalisa dengan menggunakan statistik SPSS versi 16 yaitu dengan kolmogorov-smirnov dan dilanjutkan dengan uji t-test (mann-whitney), dengan taraf kepercayaan $95 \%$. Hasil yang diperoleh menunjukkan daya lekat formula I memiliki

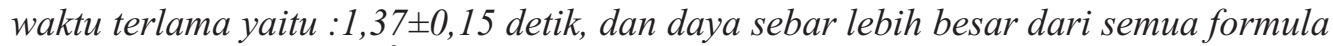

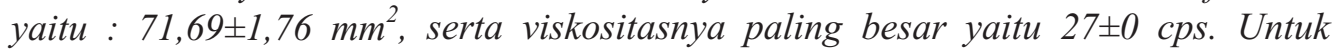
kemampuan repelan waktu yang paling lama memberikan penolakan adalah formula $V$ yaitu : 47,3 $\pm 1,80$ menit.
\end{abstract}

Kata kunci : Vanishing Cream,Repelan, minyak atsiri rimpang jahe (Zingiber officinale Roxb) 


\section{Abstract}

The essential oil of Ginger rhizome is a natural subtance which has been proved to have a repellent effect to the mosquito. The aim of this study was to know the effect of this subtance/these substances in vanishing cream dosage forms as repellant to the female Aedes aegypti mosquito. The essential oil of Ginger rhizome was isolated with aqueous vapor destillation. Then the result was determined for its physical properties, these were : viscosity, adhesivity, spreadibility and its repellant effect to mosquito as well. The vanishing cream formulation, containing variation of the essential oil concentration were prepared, these were : FI (formulation I), FII, FIII, FIV and FV, containing $6,25 \%, 12,5 \%, 15 \%, 20 \%$ and $25 \%$ of the essential oil respectivity. Each formulas were tested for their physical properties were viscosity, adhesivity, spreadibility and its repellant effect to mosquito as well. The datas were analyzed. Statistically using SPSS version 16 with Kolmogorov-Smirnov and continued with the $t$-test (Mann-Whitney) $(\alpha=0,05)$. The result showed that the duration of the adhesivity of FI was the longest than the others (1,37 00,15 minutes); the spreadibility of the FI was widest $\left(71,69 \pm 1,76 \mathrm{~mm}^{2}\right)$, and the viscosity was the largert than others $(27 \pm 0 \mathrm{cps})$. The repellant capasity of the $F V$ was the longest than the others (47,3 $\pm 1,80$ minutes).

Keyword: Vanishing cream, Repelan, The essential oil of Ginger rhizome (Zingiber officinale Roxb)

\section{PENDAHULUAN}

Demam berdarah merupakan salah satu masalah utama bagi negaranegara tropis termasuk Indonesia. Beberapa daerah di Indonesia merupakan daerah endemik demam berdarah dan banyak pasien meninggal maka menjadi kasus luar biasa. Pe- nyebab utama terjadinya penyakit ini adalah adanya vektor nyamuk Aedes aegypty. Banyak cara yang sudah dilakukan pemerintah maupun masyarakat dalam rangka mencegah terjadinya demam berdarah, yaitu dengan penyemprotan dengan DEET (diethyltoluamide), penggunaan kelambu, dan penggunaan abate untuk mencegah perkembangan jentik nyamuk dan ternyata hal ini masih kurang efektif. Terjadinya demam ber- darah diakibatkan kontak antara vektor dengan tubuh seseorang melalui proses gigitan dan ini bisa terjadi di manapun.

Sekarang banyak produk yang beredar untuk menanggulangi kontak antara vektor dengan tubuh adalah dengan penggunaan repelan (anti nyamuk ) yang dioleskan pada kulit agar terhindar dari gigitan nyamuk. Repelan yang ada di pasaran hampir semua mengandung bahan-bahan berbahaya, salah satunya adalah insektisida DEET (dethyltoluamide). Sifat DEET ini sangat korosif, sehingga dapat menyebabkan iritasi kulit. Dampak yang dirasakan langsung akibat pemakaian produk anti nyamuk berbeda-beda pada setiap individu, terutama pada anak-anak. Umumnya anak akan merasakan sesak 
nafas, batuk-batuk, pusing, mual, hingga pingsan. Dalam jangka panjang pada pemakaian produk anti nyamuk terus-menerus setiap hari bisa menimbulkan kanker paru dan kanker kulit dalam jangka waktu 5-10 tahun (Anonim, 2007).

Penggunaan insektisida banyak efek negatifnya, antara lain sulitnya residu insektisida terdegradasi sehingga selain berbahaya bagi individu juga berbahaya terhadap lingkungan. Adanya resiko penggunaan insektisida bahan kimia tersebut mendorong untuk meneliti insektisida komponen kimia dari tumbuh-tumbuhan yang toksik terhadap serangga akan tetapi mudah mengalami biodegradasi. Terkait kenyataan di atas, dunia pengobatan mulai mengalihkan perhatian pada obat-obat alam karena selain murah, efek samping yang akan timbul relatif kecil.

Hasil penelitian Soonwera (2010) menunjukan bahwa Zingiber cassumunar memiliki kemampuan repelan selama $70 \pm 17$ menit untuk menolak gigitan nyamuk Aedes aegypti, sedang terhadap nyamuk Anopheles minimus memiliki kemampuan repelan sebesar $120 \pm 0$ menit. Penelitian lain yang dilakukan oleh Thavara dkk (2007) Zingiber officinale memiliki kemampuan repelan $85,0 \pm 1,8$ menit terhadap nyamuk $P$. Americana, $95,0 \pm 1,3$ menit terhadap B. Germanica dan $70,0 \pm 8,1$ menit terhadap $N$. Rhombifolia. Dari penelitian ini maka peneliti ingin mengembangkan minyak atsiri Zingiber officinale Roxb menjadi sediaan vanishing cream yang dapat digunakan repelan.
Vanishing cream merupakan suatu sediaan setengah padat, berupa emulsi mengandung air tidak kurang dari $60 \%$ dan dimaksudkan untuk pemakaian luar. Krim akan rusak jika terganggu sistem campurannya yang dapat disebabkan perubahan suhu dan perubahan salah satu fase secara berlebihan. Rimpang jahe mempunyai minyak atsiri yang tidak tahan panas dan ditujukan untuk pemakaian luar tubuh sehingga sangat tepat untuk dibuat sediaan vanishing cream. Penelitian ini diharapkan dapat memperoleh sediaan repelan topikal yang berasal dari alam sebagai pengganti repelan sintetik yang selama ini memiliki dampak yang kurang baik berkaitan dengan toksisitas.

\section{METODE PENELITIAN}

\section{Bahan}

Bahan yang digunakan dalam penelitian ini adalah : Rimpang jahe (Zingiber officinale Roxb) yang diambil dan dibeli dari Pasar Beringharjo Yogyakarta, aquades, etanol 96\%, larutan gula $10 \%$, Asam stearat, malam putih, vaselin putih, trienolamin, propilen glikol.

\begin{abstract}
Alat
Alat yang digunakan dalam penelitian ini antara lain : Destilator uap dan air, Rheon 1 viscotester VT-04, alat-alat gelas, sangkar nyamuk serta aspirator.
\end{abstract}

\section{Hewan Uji dan Probandus}

Hewan uji yang digunakan adalah nyamuk Aedes aegypti betina usia 7-24 hari diambil dari laboratorium 
Parasitologi Fakultas Kedokteran UGM. Probandus yang digunakan adalah tangan relawan berjumlah 4 orang perempuan.

\section{Jalannya Penelitian}

\section{Isolasi Minyak Atsiri}

Rimpang jahe yang diperoleh dari Pasar Beringharjo Yogyakarta setelah disortasi dan diangin-angin kemudian diisolasi minyak atsirinya dengan menggunakan metode destilasi uap dan air. Destilasi dilakukan. Simplisia ditimbang dan dimasukkan dalam labu destilasi di atas bagian yang berlubang-lubang, sedangkan bagian bawah diisi air. Uap dialirkan melalui pendingin dan hasil sulingan ditampung, waktu destilasi selama 4 jam setelah tetesan pertama dengan kecepatan alir destilasi $\pm 4 \mathrm{ml} /$ menit. Minyak atsiri yang diperoleh masih tercampur dengan air sehingga airnya harus dipisahkan dengan ditambah $\mathrm{Na}_{2} \mathrm{SO}_{4}$ anhidrat (Anonim, 1985). Minyak atsiri hasil destilasi diukur volumenya dan ditampung pada wadah gelap, tertutup rapat, dilapisi alumunium foil agar terlindung cahaya dan disimpan ditempat sejuk.

\section{Pembuatan Vanishing Cream Minyak Atsiri Rimpang jahe (Zingiber officinale Roxb)}

Repelan minyak atsiri rimpang jahe berbagai variasi konsentrasi dibuat dengan cara mencampurkan minyak atsiri rimpang jahe konsentrasi $6,25 \%$ $\mathrm{v} / \mathrm{b}$ ( formula I ), $12,5 \% \mathrm{v} / \mathrm{b}$ ( formula II ),
$15 \% \mathrm{v} / \mathrm{b}$ ( formula III ), $20 \% \mathrm{v} / \mathrm{b}$ ( formula IV) dan $25 \% \mathrm{v} / \mathrm{b}$ ( formula V) kedalam basis vanishing cream dalam keadaan dingin.

Formula standar cream sebagai berikut :

$\mathrm{R} /$ Asam stearat $150 \mathrm{~g}$

Malam putih $20 \mathrm{~g}$

Vaselin putih $\quad 80 \mathrm{~g}$

Trietanolamin $15 \mathrm{~g}$

Propilenglikol $\quad 80 \mathrm{~g}$

Aquadest $\quad 655 \mathrm{~g}$ (Martin, 1993)

Adapun pembagian formulanya adalah sebagai berikut :

Formula I, konsentrasi $6,25 \% \mathrm{v} / \mathrm{b}$ : Minyak atsiri rimpang jahe sebanyak $0,3125 \mathrm{ml}+$ vanishing cream ad 5 gram.

Formula II, konsentrasi $12,5 \% \mathrm{v} / \mathrm{b}$ : Minyak atsiri rimpang jahe sebanyak $0,625 \mathrm{ml}+$ vanishing cream ad 5 gram

Formula III, konsentrasi $15 \% \mathrm{v} / \mathrm{b}$ : Minyak atsiri rimpang jahe sebanyak $0,75 \mathrm{ml}+$ Vanishing cream ad 5 gram

Formula IV, konsentrasi $20 \% \mathrm{v} / \mathrm{b}$ : Minyak atsiri rimpang jahe sebanyak $1 \mathrm{ml}+$ vanishing cream ad 5 gram

Formula V, konsentrasi $\quad 25 \% \quad \mathrm{v} / \mathrm{b}$ Minyak atsiri rimpang jahe sebanyak $1,25 \mathrm{ml}+$ 


\author{
vanishing cream ad 5 \\ gram
}

Malam putih, asam sterarat dan vaselin putih dilelehkan diatas penangas air pada suhu $75^{\circ} \mathrm{C}$. Trietanolamin (TEA) dan propilenglikol dilarutkan dalam air hangat suhu $75^{\circ} \mathrm{C}$. Campuran TEA dan propilenglikol tersebut kemudian dimasukan ke dalam lelahan malam putih, asam sterarat dan vaselin putih lalu aduk sampai homogen dalam mortir hangat. Setelah krim dingin kemudian tambahkan minyak atsiri rimpang jahe ke dalam krim.

\section{Uji Efek Repelan Vanishing cream minyak rimpang jahe}

Sangkar yang digunakan berukuran 20 $\mathrm{cm} \times 20 \mathrm{~cm} \times 20 \mathrm{~cm}$ dengan lubang sirkuler berdiameter $15 \mathrm{~cm}$ dan jumlah nyamuk per sangkar 20 ekor nyamuk Aedes aegypti betina dewasa yang belum pernah digigitkan, pra perlakuan hewan uji adalah dengan dipuasakan sehari sebelum percobaan. Pada tangan yang akan diolesi sediaan dipastikan bebas dari pengaruh bahan kimia lainnya dengan cara mencuci tangan dengan sabun selanjutnya dibilas dengan etanol $96 \%$ dan didiamkan selama \pm 2-3 menit kemudian dioleskan sampel pada tangan relawan sebanyak 1 gram. Uji repelan menggunakan dan mengacu pada metode yang dilakukan oleh Fradin dan Day (2002) yang dimodifikasi. Pada masingmasing pengujian dilakukan replikasi sebanyak 4 kali. Semua perlakuan dilakukan pada pagi hingga siang hari dari pukul 8.00-11.00 wib mengikuti perilaku nyamuk Aedes aegypti.

\section{Uji sifat fisik vanishing cream minyak atsiri rimpang jahe}

Dalam menjamin kualitas farmasetik, sediaan yang dibuat harus memenuhi beberapa parameter fisik yang meliputi daya sebar, viskositas, dan daya lekat, uji sifat fisik repelan dilakukan setelah dilakukan uji anti nyamuk pada repelan minyak atsiri rimpang jahe dalam basis Vanishing cream dengan berbagai konsentrasi.

\section{a. Uji daya sebar}

Setengah $(0,5)$ gram sediaan repelan diletakkan diatas kaca bulat berskala, kemudian ditutup dengan menggunakan kaca bulat yang tidak berskala yang telah diketahui bobotnya selama 1 menit, dicatat diameter penyebarannya, dilanjutkan dengan beban 50 gram, 100 gram, dicatat diameter penyebaran repelan, dilakukan replikasi sebanyak 3 kali.

b. Uji daya lekat

Uji daya lekat dilakukan dengan cara sediaan repelan diratakan pada objek glas dengan ukuran kurang lebih 3 $\mathrm{cm} \times 2 \mathrm{~cm}$, kemudian ditutup dengan objek glass lain, ditekan dengan beban seberat $1 \mathrm{~kg}$ selama 5 menit. Objek glass dipasang pada alat uji dilepas dengan beban seberat 80 gram dan waktu yang diperlukan untuk memisahkan kedua objek glass tersebut dicatat. Pengujian dilakukan sebanyak 5 kali untuk masingmasing konsentrasi. 


\section{c. Uji viskositas}

Untuk menentukan viskositas cream minyak atsiri rimpang jahe adalah dengan cara menimbang cream minyak atsiri rimpang jahe sebanyak $10 \mathrm{~g}$ kemudian diuji menggunakan alat menggunakan alat Rheon 1 viscotester VT-04.

\section{ANALISIS DATA}

Data waktu aktivitas repelan dan data hasil uji sifat fisik (daya lekat, daya sebar dan viskositas) repelan diuji homogenitas dan test KolmogorovSmirnov dengan SPSS versi 16. Bila data terdistribusi normal pada test Kolmogorov-Smirnov $(\alpha \geq 0,05)$ dan homogen pada uji homogenitas $(\alpha \geq$ $0,05)$, maka dilakukan uji parametrik one way Anova dan post hock test. Apabila tidak sesuai dengan ketentuan tersebut, dilanjutkan uji non parametrik KruskalWalls dan Mann-whitney. Data berbeda bermakna bila pada uji parametrik atau pada uji non parametrik $\alpha \leq 0,05$.

\section{HASIL DAN PEMBAHASAN}

Tujuan penelitian ini adalah untuk mengetahui efek repelan atau kemampuan tolak nyamuk vanishing cream minyak atsiri rimpang rimpang jahe (Zingiber officinale Roxb) terhadap nya muk Aedes aegypti betina sebagai vektor demam berdarah dan uji sifat fisik sediaannya. Penelitian ini diharapkan dapat memberikan alternatif sediaan repelan dari bahan alam yang efektif dan aman dalam memberikan perlindungan terhadap gigitan nyamuk Aedes aegypti khususnya.

\section{Hasil Pembuatan Minyak Atsiri Rimpang Jahe}

Minyak atsiri diperoleh dari rimpang jahe (Zingiber officinale Roxb) dengan cara destilasi uap air. Dimana metode ini memanfaatkan uap air dari air yang mendidih. Uap air ini kemudian menembus kedalam sel simplisia dan membawa minyak atsiri melewati saluran lalu menetes menjadi 2 fase, air dan minyak atsiri. Fase minyak dan air dipisahkan. Untuk menghilangkan jejak air dalam minyak atsiri ditambahkan $\mathrm{Na}_{2} \mathrm{SO}_{4}$ anhidrat kemudian disaring.

\section{Uji Sifat Fisik Minyak Atsiri}

Sifat fisik minyak atsiri adalah salah satu parameter konstan yang diukur pada kondisi yang tetap, sifat fisik minyak atsiri ini digunakan untuk mengetahui kemurnian minyak atsiri dan menentukan mutu minyak atsiri (Anonim, 1985). Hasil uji sifat fisik minyak atsiri meliputi:

a. Hasil uji organoleptis: minyak atsiri rimpang jahe mempunyai bau khas aromatik, rasa pedas tajam dan berwarna kuning jernih.

b. Penetapan indek bias merupakan salah satu cara untuk menguji sifat fisik minyak atsiri yang bertujuan untuk menguji kemurnian minyak atsiri. Penentuan indek bias minyak atsiri rimpang jahe dilakukan di Laboratorium Kimia Organik Universitas Ahmad Dahlan. Hasil penetapan indeks bias minyak atsiri rimpang jahe adalah 1,493 pada suhu $31,1^{\circ} \mathrm{C}$. Dalam buku "The Essential Oil" dicantumkan bahwa minyak atsiri rimpang jahe adalah 1,490 1,498 pada suhu $20^{\circ}$ C. Hal ini 
menunjukkan bahwa indeks bias minyak atsiri rimpang jahe sesuai dengan standar (Guenther, 1987).

\section{Uji Pendahuluan Basis Vanishing Cream}

Uji pendahuluan atau orientasi ini dilakukan bertujuan untuk menemukan formula terbaik berdasarkan pada sifat fisik vanishing cream khususnya stabilitas creamnya. Dengan stabilitas sifat fisik vanishing cream maka diharapkan akan memberikan efek repelan yang lebih baik. Hasil orientasi ini maka peneliti menetapkan konsentrasi minyak atsiri jahe diatas $25 \% \mathrm{v} / \mathrm{b}$ cream mengalami creaming atau pecah dengan ditandai pemisahan antara fase minyak dengan fase air, berarti pada konsentrasi tersebut vanishing cream melewati batas maksimum perbandingan basis cream dengan minyaknya. Selanjutnya dalam formula vanishing cream lebih lanjut konsentrasi minyak atsiri ditambahkan dibawah konsentrasi $25 \% \mathrm{v} / \mathrm{b}$.

\section{Hasil Uji Sifat Fisik Vanishing Cream Minyak Atsiri Rimpang Jahe}

Ketiga formula tersebut maka selanjutnya dilakukan uji sifat fisik sediaannya yang meliputi uji viskositas, uji daya lekat, uji daya sebar dan daya repelan dari vanishing cream tersebut.

a. Uji Viskositas Vanishing Cream Minyak Atsiri Rimpang Jahe.

Uji viskositas vanishing cream bertujuan untuk mengetahui kualitas vanishing cream Hasil uji daya lekat dapat dilihat pada Tabel I.

Dari hasil uji viskositas dapat dilihat Tabel I pada formula I diperoleh $(27 \pm 0,0) \mathrm{cps}$, formula II $(16,9 \pm 0,22) \mathrm{cps}$, formula III $(15,1 \pm 0,22) \mathrm{cps}$, formula, formula IV $(9,08 \pm 0,11) \mathrm{cps}$ dan formula V $(8,08 \pm 0,11)$ cps. Hasil viskositas ini menunjukkan bahwa dengan semakin besarnya konsentrasi minyak atsiri jahe dalam vanishing cream menunjukkan viskositasnya semakin menurun karena kandungan tanin dalam minyak atsiri rendah. Hal ini dapat dilihat pada Gambar 1 berikut ini.

Tabel I. Hasil Uji Viskositas Vanishing Cream Minyak Atsiri Jahe

\begin{tabular}{|c|c|c|c|c|c|}
\hline \multirow{2}{*}{ No. } & \multicolumn{5}{|c|}{ Data Viskositas Cream Minyak Atsiri Jahe (cps) } \\
\cline { 2 - 6 } & FI (6,25\%) & FII (12,5\%) & FIII (15\%) & FIV (20\%) & FV (25\%) \\
\hline 1 & 27 & 17 & 15,5 & 9 & 8 \\
\hline 2 & 27 & 17 & 15 & 9 & 8,2 \\
\hline 3 & 27 & 16,5 & 15 & 9,2 & 8,2 \\
\hline 4 & 27 & 17 & 15 & 9,2 & 8 \\
\hline 5 & 27 & 17 & 15 & 9 & 8 \\
\hline
\end{tabular}




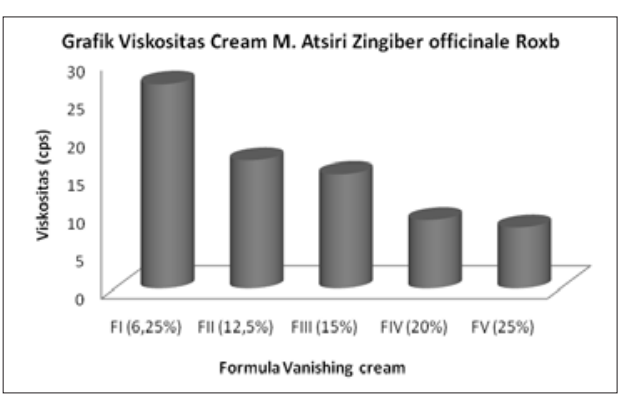

Gambar 1. Grafik viskositas vanishing cream m. atsiri jahe

Hasil statistik menggunakan SPSS versi 16 menunjukkan kelima formula memiliki viskositas yang berbeda bermakna antar kelompok formula, dimana nilai signifikansinya $<0,05$. Berarti dengan penambahan konsentrasi minyak atsiri dalam vanishing cream menunjukkan bahwa keberbedaan viskositas creamnya.

b. Uji Daya Lekat Vanishing Cream Minyak Atsiri Rimpang Jahe.

Uji daya lekat vanishing cream bertujuan untuk mengetahui waktu yang dibutuhkan cream tersebut untuk menempel pada kulit dan mengetahui pengaruh konsentrasi minyak atsiri rimpang jahe terhadap daya lekatnya. Hasil penelitian menunjukkan bahwa semakin tinggi kadar minyak atsiri rimpang jahe maka daya lekatnya semakin menurun, hal ini dapat dilihat pada Tabel II berikut ini.

Dengan bertambahnya konsentrasi minyak atsiri yang terkandung dalam vanishing cream maka kemampuan daya lekatnya makin menurun, hasil daya lekat berturut-turut formula I $(1,37 \pm 0,15)$ detik, formula II $(0,66 \pm 0,02) \quad$ detik, formula III $(0,67 \pm 0,02)$ detik detik, formula IV $(0,13 \pm 0,03)$ detik dan formula V diperoleh daya lekatnya paling cepat yaitu $0,06 \pm 0,02$ detik sedangkan yang paling lama daya lekatnya adalah formula I dengan waktu $(1,37 \pm 0,15)$ detik. Hal disebabkan dengan bertambahnya konsentrasi minyak atsiri maka viskositas makin kecil karena karakter sifat fisik minyak atsiri rimpang yang rendah viskositasnya disebabkan kadar air lebih banyak dibanding kadar taninnya sehingga berpengaruh pada daya lekatnya. Untuk grafik kemampuan

Tabel II. Uji Daya Lekat Vanishing Cream Minyak Atsiri Rimpang Jahe

\begin{tabular}{|c|c|c|c|c|c|}
\hline \multirow{2}{*}{ No. } & \multicolumn{5}{|c|}{ Daya Lekat Vanishing Cream Minyak Atsiri Jahe (detik) } \\
\cline { 2 - 6 } & FI (6,25\%) & FII (12,5\%) & FIII (15\%) & FIV (20\%) & FV (25\%) \\
\hline 1 & 1,26 & 0,65 & 0,67 & 0,15 & 0,07 \\
\hline 2 & 1,52 & 0,67 & 0,68 & 0,15 & 0,08 \\
\hline 3 & 1,27 & 0,63 & 0,67 & 0,10 & 0,05 \\
\hline 4 & 1,55 & 0,68 & 0,65 & 0,10 & 0,05 \\
\hline 5 & 1,27 & 0,65 & 0,70 & 0,17 & 0,03 \\
\hline $\mathrm{X} \pm \mathrm{SD}$ & $1,37 \pm 0,15$ & $0,66 \pm 0,02$ & $0,67 \pm 0,02$ & $0,13 \pm 0,03$ & $0,06 \pm 0,02$ \\
\hline
\end{tabular}


daya lekat vanishing cream dapat dilihat pada Gambar 2.

Hasil uji statistik menunjukkan bahwa antar formula menunjukkan adanya perbedaan kecuali formula II dan formula III menunjukkan nilai signifikansi $0,691>0,05$ yang artinya antara formula II dan formula III menunjukkan hasil berbeda tidak bermakna, Sedangkan untuk hasil statistik formula IV dengan formula $\mathrm{V}$ menunjukkan nilai signifikansi $0,147>0,05$ berarti antara formula IV dan $\mathrm{V}$ menunjukkan hasil berbeda tidak bermakna.

\section{c. Uji Daya Sebar Vanishing Cream Minyak Atsiri Rimpang Jahe}

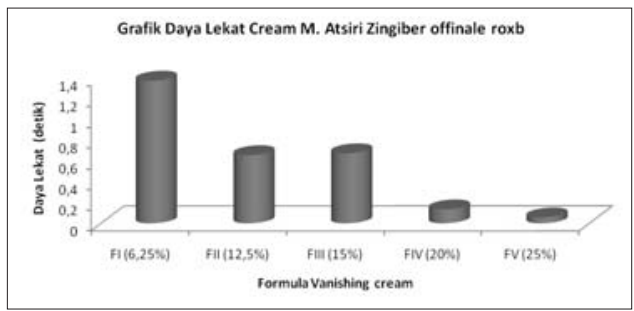

Gambar 2. Grafik daya lekat vanishing cream m. atsiri jahe
Uji daya sebar vanishing cream bertujuan untuk mengetahui kemampuan menyebar pada cream pada saat dioleskan pada kulit dan pengaruh penambahan konsentrasi minyak atsiri terhadap daya sebarnya. Hasil uji daya sebar dapat dilihat pada Tabel III sebagai berikut.

Hasil uji daya sebar menunjukkan pada formula I diperoleh daya sebar $(71,69 \pm 1,757) \mathrm{mm}^{2}$ dan formula II memiliki daya sebar yaitu $(68,10 \pm 4,343)$ $\mathrm{mm}^{2}$, formula III $(71,21 \pm 6,925) \mathrm{mm}^{2}$, formula IV $(73,69 \pm 3,547)$ sedangkan yang memiliki daya sebar yang paling rendah adalah formula $\mathrm{V}$, yaitu $(62,94 \pm 0,456) \quad \mathrm{mm}^{2}$. Secara logika teoritis formula $\mathrm{V}$ seharusnya memiliki daya sebar yang lebih besar dibanding formula I, II, III dan IV karena konsentrasi minyak atsiri rimpang jahe lebih banyak sehingga dengan penambahan minyak atsiri rimpang jahe kekentalan semakin berkurang. Hal ini kemungkinan dipengaruhi homogenitas vanishing cream karena keterbatasan kemampuan emulgator untuk menurunkan tegangan permukaan antara fase minyak dan fase air, dimungkinkan perbandingan fase minyak dan fase air di formula $\mathrm{V}$ telah melebihi kemampuan

Tabel III. Uji Daya Sebar Vanishing Cream Minyak Atsiri Rimpang Jahe

\begin{tabular}{|c|c|c|c|c|c|}
\hline \multirow{2}{*}{ No. } & \multicolumn{5}{|c|}{ Daya Sebar Cream Minyak Atsiri Jahe (mm $\mathbf{~})$} \\
\cline { 2 - 6 } & FI (6,25\%) & FII (12,5\%) & FIII (15\%) & FIV (20\%) & FV (25\%) \\
\hline 1 & 73,1 & 69,72 & 79,21 & 76,54 & 63,2 \\
\hline 2 & 69,72 & 63,18 & 67,2 & 74,82 & 62,41 \\
\hline 3 & 72,24 & 71,4 & 67,23 & 69,72 & 63,2 \\
\hline $\mathrm{X} \pm \mathrm{SD}$ & $71,69 \pm 1,757$ & $68,10 \pm 4,343$ & $71,21 \pm 6,925$ & $73,69 \pm 3,547$ & $62,94 \pm 0,456$ \\
\hline
\end{tabular}




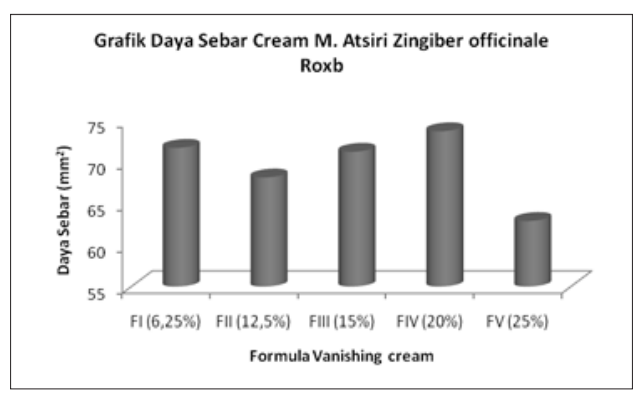

Gambar 3. Grafik daya sebar vanishing cream $\mathrm{m}$. atsiri rimpang jahe

emulgatornya sehingga pencampuran tidak sempurna.

Perbandingan daya sebar antar formula dapat dilihat pada gambar 3 .

Hasil analisa statistik menunjukkan bahwa formula $\mathrm{V}$ bermakna beda bermakna dengan formula I, III dan IV, sedangkan formula $\mathrm{V}$ dengan formula II menunjukkan berbeda tidak bermakna dengan nilai signifikansi adalah 0,151 , berarti antara formula I, III dan IV memiliki daya sebar yang sama sedangkan formula II dan $\mathrm{V}$ juga memiliki daya sebar yang sama.

\section{d. Uji Daya Repelan Terhadap Nyamuk Aedes aegypti Betina}

Penelitian dilakukan pada waktu pagi hari jam 08.00-11.00 mengikuti perilaku nyamuk Aedes aegypti yang menggigitnya dalam periode waktu menjelang tengah hari berkisar antara pukul 08.00-11.00 bertempat di laboratorium Teknologi Farmasi Fakultas Farmasi UAD Yogyakarta. Kondisi ruangan tenang, dengan cahaya tidak terlalu terang, dan pada suhu kamar $250-27^{\circ} \mathrm{C}$. Hal ini bertujuan untuk mengkondisikan ruangan sesuai dengan habitat nyamuk Aedes aegypti. Apabila cahaya terang dan kelembaban tinggi akan menyebabkan nyamuk kelelahan dan mengganggu antena chemoreseptor sehingga akan mencegah nyamuk untuk menggigit (Fradin dan Day, 2002). Hasil uji repelan dapat dilihat pada tabel IV, pada tabel tersebut formula $\mathrm{V}$ memiliki kemampuan penolakan nyamuk paling lama dibanding formula I, II, III dan IV yaitu 47,3 $\pm 1,8$ menit . Formula V memiliki daya repelan paling lama hampir satu jam karena mengandung minyak atsiri sere sebanyak $25 \% \mathrm{v} / \mathrm{b}$, sedangkan formula I, II, III dan IV daya repelan berturut-turut adalah 15,8 $\pm 0,4$ menit, $16,9 \pm 0,3$ menit, $18,3 \pm 0,6$ menit dan $19,7 \pm 1,8$ menit. Perbedaan kemampuan repelan ini dipengaruhi oleh jumlah minyak atsiri yang masih terkandung dalam sediaan. Hasil uji statistik menunjukkan bahwa semua formula berbeda bermakna kecuali formula I dengan formula II memiliki hasil berbeda tidak bermakna dengan nilai signifikansi $0,076>0,05$.

Dari gambar 4 dapat dilihat grafik daya repelan vanishing cream minyak rimpang jahe menunjukkan bahwa formula $\mathrm{V}$ memiliki daya repelan yang paling lama dibanding formula I, II, III dan IV.

Kandungan minyak atsiri rimpang jahe berorama harum dan pedas karena mengandung 6-gingerol dan 6-shogaol, hal ini menyebabkan nyamuk tidak menyukai bau pedas dari minyak atsiri rimpang temulawak yang juga bersifat volatil sehingga dengan semakin banyak konsentrasinya maka aroma pedas semikin menyengat. 
Tabel IV. Uji daya repelan vanishing cream $\mathrm{m}$. atsiri rimpang jahe

\begin{tabular}{|c|c|c|c|c|c|}
\hline \multirow{2}{*}{ No. } & \multicolumn{5}{|c|}{ Data Repelan Cream Minyak Atsiri Jahe (Menit) } \\
\cline { 2 - 6 } & FI (6,25\%) & FII (12,5\%) & FIII (15\%) & FIV (20\%) & FV (25\%) \\
\hline 1 & 15,83 & 17,33 & 18,67 & 19,93 & 49,28 \\
\hline 2 & 16,35 & 16,78 & 17,93 & 19,98 & 46,15 \\
\hline 3 & 16,17 & 16,58 & 17,45 & 18,62 & 45,88 \\
\hline 4 & 15,37 & 16,70 & 18,82 & 19,97 & 45,92 \\
\hline 5 & 15,43 & 17,23 & 18,77 & 19,83 & 49,25 \\
\hline rata-rata & 15,83 & 16,924 & 18,328 & 19,666 & 47,296 \\
\hline SD & 0,4352011 & 0,334559 & 0,609032 & 0,587733 & 1,800425 \\
\hline
\end{tabular}

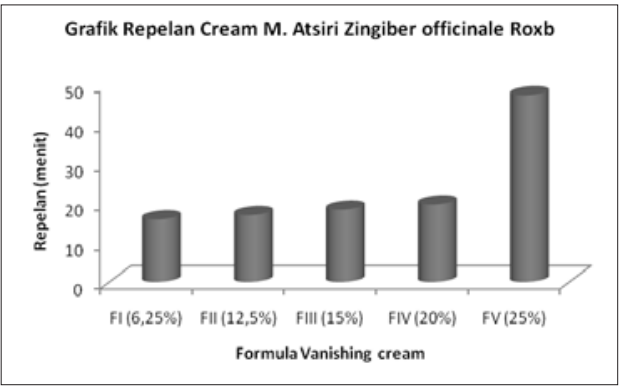

Gambar 4. Grafik Hasil Uji Daya Repelan Vanishing Cream Minyak Sere dan Basis

\section{KESIMPULAN DAN SARAN}

\section{Kesimpulan}

1. Minyak atsiri rimpang jahe (Zingiber officinale Roxb) dapat dibuat sediaan vanishing cream dengan konsentrasi minyak jahe $6,25 \% \mathrm{v} / \mathrm{b} ; 12,5 \% \mathrm{v} / \mathrm{b}$, $15 \% \mathrm{v} / \mathrm{b}, 20 \% \mathrm{v} / \mathrm{b}$ dan lebih $25 \% \mathrm{v} / \mathrm{b}$ sediaan vanishing cream pecah.
2. Penambahan minyak atsiri rimpang jahe (Zingiber officinale Roxb) mempengaruhi daya lekat dengan semakin banyak konsentrasi minyak atsirinya maka daya lekat semakin cepat, sehingga formula I lebih lama daya lekatnya dibanding formula II, III,IV dan V.

3. Daya sebar dari formula I, III dan IV menunjukkan hasil berbeda tidak bermakna sedangkan formula II dan $\mathrm{V}$ menunjukkan hasil berbeda tidak bermakna, dan formula III memiliki daya sebar yang paling besar yaitu $73,7 \pm 3,5 \mathrm{~mm}^{2}$.

4. Formula yang memiliki kemampuan daya repelan terlama adalah formula $\mathrm{V}$ dengan waktu penolakan $47,3 \pm 1,8$ menit.

\section{Saran}

1. Perlu dilakukan optimasi emulgator pada formula vanishing cream minyak atsiri rimpang jahe (Zingiber officinale Roxb) sehingga dapat 
meningkatkan stabilitas sediaan dan efek repelannya.

2. Perlu dilakukan uji stabilitas vanishing cream berkaitan dengan stabilitas kandungan minyak atsiri rimpang jahe (Zingiber officinale Roxb) dalam sediaan.

\section{DAFTAR PUSTAKA}

Anonim. 2004. Informasi Penyakit Menular.

http://ppmplp.depkes.go.id 3 Maret 2004.

Anonim. 2007. Tanaman Pengusir Nyamuk.

http://www.HarianGlobal.com/ne ws. 12 Mei 2007.

Fradin, S.M., dan Day, F.D, 2002, Comparative Efficacy of Insect Repellents against Mosquito Bites, The New England Journal of Medicine, Chapel Hill Dermatology, Vol.347 : 13-18, mark_fradin@med.unc.edu diakses pada tahun 2006 .
Guenther.E.,1987, Minyak Atsiri. Jilid I. Jakarta: Penerbit Universitas Indonesia.

Soonwera, S. P. a. M. (2010). "Insect Repellent Activity Of Medicinal Plant Oils Against Aedes aegypti (Linn.), Anopheles minimus (Theobald) And Culex Quinquefasciatus Say Based On Protection time And Biting Rate." Southeast Asian J Trop Med Public Health 41.

Usavadee Thavara, A. T., Payu Bhakdeenuan, Prapai Wongsinkongman,, J. B. Thidarat Boonruad, Pranee

Chavalittumrong, Narumon Komalamisra, et al. (2007). "Repellent Activity Of Essential Oils Against Cockroaches (Dictyoptera:

Blattidae,Blattellidae, And Blaberidae) In Thailand." Southeast Asian J Tropical Medical Public Health 38. 